\title{
Gender Inequality and Land Rights: The Situation of Indigenous Women in Cameroon
}

EE Njieassam*

\section{P.E.R}

Pioneer in peer-reviewed, open access online law publications

Author

Ester E Njieassam

Affiliation

University of Johannesburg

South Africa

Email

esthere@uj.ac.za

Date Submission

9 April 2018

Date Revised

26 September 2018

Date Accepted

28 January 2019

Date published

26 April 2019

Editor Prof M Carnelley

How to cite this article

Njieassam EE "Gender Inequality and Land Rights: The Situation of Indigenous Women in Cameroon" PER / PELJ 2019(22) - DOI http://dx.doi.org/10.17159/17273781/2019/v22i0a4907

\section{Copyright}

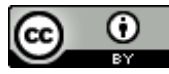

DOI

http://dx.doi.org/10.17159/17273781/2019/v22i0a4907

\begin{abstract}
Land is an essential resource that serves as a means of subsistence for millions of people in the world and indigenous communities and women in particular. Most indigenous societies' survival is closely tied to land. In Cameroon, indigenous women are the backbone of food production in their communities. That makes access to land important, as it is a significant source of wealth and power for indigenous peoples in general and indigenous women in particular. While women all over the world encounter gender-based discrimination in relation to the control and ownership of land, indigenous women face triple discrimination on the basis of their gender (as women), their ethnicity (as indigenous peoples) and their economic class (economically poor). They are often dehumanised, degraded and subjected to treatment as second-class human beings despite the existence of national legislation that discourages such practices. This paper interrogates the possibility of including indigenous women in government and decisionmaking processes in Cameroon in the hope that they may be involved in key decision-making processes that affect them, thereby reducing their economic and social vulnerability. It concludes with some thoughtful recommendations on policy reform aimed at ensuring access to land for indigenous women as well as socio-economic justice in its broadest sense.
\end{abstract}

\section{Keywords}

Indigenous women; gendered-based discrimination; land rights; gender inequality; decision-making; participation; Cameroon. 


\section{Introduction}

Land is an essential resource that serves as a means of subsistence for millions of people in the world and indigenous communities and women in particular. While most indigenous societies' survival is closely tied to land, their women are often the backbone of food production in their communities. ${ }^{1}$ That makes access to land important, as it is a significant source of wealth and power for indigenous peoples in general and indigenous women in particular. ${ }^{2}$ However, the recent trend of commercial and infrastructural development that is putting pressure on the traditional land of indigenous peoples is intensifying the denial of indigenous women's right to land. ${ }^{3}$ Wachira asserts that the massive loss of ancestral lands and natural resources is central to the pervasive discrimination and exclusion that indigenous peoples and their women encounter daily. ${ }^{4}$ Related studies reveal that customary practices have implanted patriarchal norms in Cameroonian society so that it is thought natural that men oppress, exploit and subordinate women, and prevent them from inheriting and controlling land. ${ }^{5}$ Sone is of the view that this practice has permitted men to make decisions and adopt laws that work in their favour to the detriment of women. ${ }^{6}$ Although indigenous women are actively involved in diverse roles in the family and community (such as child-bearing, caring for the children and the entire family, the construction of family huts, and food production), they do not have the right to own the land they use for food production. ${ }^{7}$ Therefore, the system of land tenure in Cameroon has predisposed men and women to participate in the public domain differently. ${ }^{8}$

There is a wealth of academic writing on women's right to land in Cameroon in general. However and unfortunately, the literature on indigenous women's right to land in Cameroon is scanty. This has suggested that there is a need for an investigation into the possible causes of this pervasive discrimination perpetrated against indigenous women about access to and

\footnotetext{
Esther E Njieassam. LLB (Buea) LLM LLD (NWU). Postdoctoral Research Fellow, South African Research Chair in International Law, Faculty of Law, University of Johannesburg, South Africa. E-mail: esthere@uj.ac.za.

Same and Greenen Discourses, Fragmentation and Coalitions 1-14.

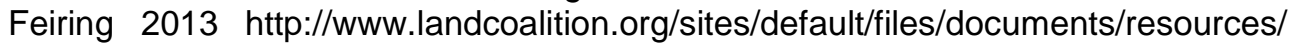
InidgneousPeoplesRightsLandTerritoriesResources.pdf 45-46. Anon 2017 http://pubs.iied.org/pdfs/17448IIED.pdf. Wachira "Indigenous Peoples' Rights to Land and Natural Resources" 299. Fonjong, Fombe and Sama-Lang 2013 GeoJournal 576.

Sone 2012 J Soc Dev Afr 87. IFAD date unknown https://www.ifad.org/documents/10180/3629656a-70f3-4c94b58f-fd1e7ea2f4dc 1-10.

$8 \quad$ Fonjong, Fombe and Sama-Lang 2013 GeoJournal 576-577.
} 
control of land. Given that indigenous peoples, especially women, are the most marginalised, disadvantaged and neglected group of people in Cameroonian society, a study of this nature becomes very important in my view.

This paper argues that the inclusion of indigenous women in government, and their participation in decision-making processes over issues that affect them, both directly and indirectly, may alleviate the crisis and ultimately change the way key issues such as access to and control over land are conducted in their communities. At the core of this paper is the argument that the inclusion of indigenous women in government (a liberal approach to public participation in the public affairs of the country as well as participation as citizens) is key to resolving the issue of access to and control over lands by indigenous women in Cameroon. In order to achieve this, this paper commences with a delineation of the indigenous peoples (and women in particular) in the Cameroonian context; as well as the different communities in which they live. This is followed by a discussion of the customary notion of land rights in the country. The paper examines the legislative framework that regulates access to land in Cameroon and the concept of gender inequality in the country is explored, especially with reference to its effects on indigenous women's right to land.

\section{The origins of the indigenous peoples of Cameroon}

The genesis of the indigenous peoples of Cameroon is as complex as the concept itself. Even though very limited or no literature exists in dealing with the origin of this group of people, several sources attest to the fact that they were the first inhabitants or "first peoples" to settle in the tropical forest of Cameroon before European colonisation. ${ }^{9}$ I will adopt the appellation "Pygmies" and "Mbororos" to refer to those groups who self-identify as indigenous peoples in Cameroon. Although there are some controversies, regarding the term "indigenous peoples" as it is considered insulting and derogatory, over time many indigenous peoples have preferred the name as it distinguishes them from the rest of the society. ${ }^{10}$

However, the mystery of how and where they originate from remains a debatable subject amongst academics. Verdu is of the opinion that the

\footnotetext{
9 CEDD, RACOPY and FPP 2010 http://www.forestpeoples. org/en/partners/ced/publication/2010/situation-indigenous-peoples-cameroonsupplementary-report-un-committe 9.

10 Survival International date unknown http://wwwsurvivalinternational org/tribes/pygmies.
} 
"Pygmies" in Western Central Africa have existed for over 2,800 years and originated from an ancestral group 70,000 years ago that gave birth to the non-pygmy population. ${ }^{11}$ History holds that the Bakas were the first inhabitants to settle at the borders of the southern and eastern regions of Cameroon. ${ }^{12}$ They self-identify as "forest peoples" or "indigenous peoples" based on the spiritual attachment they have with the forests as well as the belief that they are the original inhabitants of the African tropical forests. ${ }^{13}$ The forest to them is a symbol of security and peace and must be preserved for future generations. ${ }^{14}$ As their primary occupations are hunting, fishing and gathering, their existence depends on the land, especially because the majority of them (women) have adopted a sedentary lifestyle with agriculture as their primary way of life.

On the other hand, the Mbororos in the North-West region of Cameroon (also known as the Fulani or Nomadic Fulani) originate from the Kano region, the present-day Nigeria, and from an ethnic group called Fulbe. ${ }^{15}$ They then migrated through the Sahel and Savannah belt from West to East Africa around the 19th century in search of fertile regions for cattle grazing and favourable political conditions. ${ }^{16}$ The favourable climatic conditions in Bamenda enabled their settlement. ${ }^{17}$ Other scholars believe that this group of people originated from the Berber community of North Africa and SubSahara Africa between the 8th and 11th century AD. ${ }^{18}$ They then journeyed through the Middle East and later migrated to Senegal and eventually scattered throughout West and Central Africa and the borders of Ethiopia between 900-1900 AD. ${ }^{19}$ This group of people have always retained a

\footnotetext{
11 Survival International date unknown http://wwwsurvivalinternational org/tribes/pygmies.

12 ILO 2015 https://www.ilo.org/gender/Informationresources/Publications/WCMS 438854/lang--en/index.htmpdf.

13 Anadolu Agency 2017 https://www.dailysabah.com/feature/2017/08/03/insidecameroons-pygmy-community-traditions-lifestyle-and-religion; Mawoung 2001 African Study Monographs 209.

14 CEDD, RACOPY and FPP 2010 http://www.forestpeoples.org/ en/partners/ced/publication/2010/situation-indigenous-peoples-cameroonsupplementary-report-un-committe 9.

15 Anter 2011 https://www.modernghana.com/news/349849/1/who-are-the-fulanipeople-their-origins.html.

$16 \quad$ Pelican 2009 American Ethnologist 57.

17 It is important to note that although the Mbororos are scattered through all the provinces of Cameroon, most of them are settled in the North West Province of Cameroon, which is called Bamenda, and have adopted a sedimentary lifestyle; Pelican 2009 American Ethnologist 58.

18 Anter 2011 https://www.modernghana.com/news/349849/1/who-are-the-fulanipeople-their-origins.html.

19 Anter 2011 https://www.modernghana.com/news/349849/1/who-are-the-fulanipeople-their-origins.html.
} 
nomadic lifestyle as herders and traders, which led to their developing several trade routes throughout West Africa. ${ }^{20}$ Although recently most of them have also adopted a sedentary lifestyle, like the "Pygmies", they are still regarded as strangers and face significant challenges (especially the Mbororo women) regarding land ownership, and their exclusion from political spheres and decision-making processes.

The indigenous peoples have a unique lifestyle with a special connection to the environment, land and natural resources. ${ }^{21}$ The "Pygmy" and "Mbororo" women in Cameroon face similar problems of acute marginalisation, gender-based discrimination, segregation, rejection, poverty and denial of rights to land. ${ }^{22}$ Customary laws and the legal framework regulating land tenure and property rights threaten the integrity and security of indigenous women's access to and right to land.

\subsection{The identification of the indigenous peoples of Cameroon}

The identification of the indigenous peoples remains an ambiguous and challenging subject in Cameroon, especially in the absence of a universal definition of the concept. Most African states are reluctant to acknowledge the existence of indigenous peoples in their community and Cameroon is no exception. ${ }^{23}$ International instruments specifically involved in promoting the rights of indigenous peoples such as the ILO Convention No 169 and the United Nations Declaration on the Rights of Indigenous Peoples (UNDRIP) ${ }^{24}$ do not adequately define the concept. This controversy was resolved (though this was not binding on states parties) when the African Commission on Human and Peoples Rights Working Group on Indigenous Populations/Communities outlined specific characteristics that describe and identify indigenous peoples in Africa.

It became clear in terms of the above that two groups in Cameroon meet the criteria and qualify as indigenous peoples: the Mbororo nomadic pastoralists and the hunter-gatherer communities known as the Forest Peoples or the "Pygmies". ${ }^{25}$ Despite this, the Constitution of Cameroon failed to adequately protect the rights of indigenous peoples' and to

\footnotetext{
20 Anter 2011 https://www.modernghana.com/news/349849/1/who-are-the-fulanipeople-their-origins.html. Abate and Kronk 2013 Tul Envtl LJ 180. Coates Global History of Indigenous Peoples 138. Gilbert 2017 ICLQ 658. United Nations Declaration on the Rights of Indigenous Peoples (2007) (UNDRIP). ILO 2015 https://www.ilo.org/gender/Informationresources/Publications/WCMS 438854/lang--en/index.htm.
} 
specifically state which groups are classified as indigenous peoples. ${ }^{26}$ Based on this, the government launched a study in 2009 aimed at investigating groups that qualify as indigenous peoples in Cameroon. ${ }^{27}$ It is only recently that Cameroon has begun recognising the concept of indigeneity, after identifying certain groups as indigenous. ${ }^{28}$ It is arguable that government acknowledges the existence of indigenous groups only when international organisations such as the World Bank intend funding indigenous programmes in an effort to improve their living conditions. ${ }^{29}$ That notwithstanding, no group in Cameroon has been officially recognised as indigenous. Such people are often classified as "marginal populations" or "vulnerable groups". ${ }^{30}$ It is therefore correct to say that the recurrent discrimination against indigenous women with regard to land tenure rights may be attributed to the lack of adequate recognition in the national Constitution. To this end, these groups continue to experience extreme levels of poverty, political repression and worse forms of economic and social inequality than non-indigenous women.

\section{The customary notion of land rights in Cameroon}

In Cameroon, as in most other African states, customary law constitutes a major source of law and is a vital part of the legal system. It has been given constitutional acknowledgement and protection, particularly with regard to customary land tenure and the various institutions governing it. ${ }^{31}$ Customary laws are defined as the laws, practices and customs of indigenous and local communities. ${ }^{32}$ They are usually unwritten social rules and structures of a community derived from their shared values based on tradition. ${ }^{33}$ These rules serve as laws that are respected by and binding on every individual in the community. Some scholars contend that these norms were tricks of the

26 See para 5(2) of the Constitution of the Republic of Cameroon, 1996.

27 ILO 2015 https://www.ilo.org/gender/Informationresources/Publications/WCMS _438854/lang--en/index.htm. This study is still to be finalised. Progress has been made, and it is presently in its second stage.

See Bakang Mbock Speech; Nguh Implementing the Basic International Law Principles 8; ACHPR 2010 http://www. achpr.org/states/cameroon/reports/2nd-20032005/ 119-120; Ministry of Justice Cameroon Report on Human Rights 271; CEDD, RACOPY and FPP 2010 http://www.forestpeoples.org/en/partners/ced/ publication/2010/situation-indigenous-peoples-cameroon-supplementary-report-uncommitte 13.

Pelican 2013 Anthropol Today 13-14.

Pelican 2013 Anthropol Today 13.

Ossome 2014 Feminist Economics 155.

WIPO $2013 \quad \mathrm{http}: / / \mathrm{www} . w i p o . i n t / e x p o r t / s i t e s / w w w / t k / e n / r e s o u r c e s / p d f /$ overview_customary_law.pdf. 
colonialists to ensure rapid social change and instability in the society. ${ }^{34}$ For example, Chanock thinks that customary law is a colonial construct or tool embedded in law by both the white colonial masters and their black counterparts to establish a patriarchal order in the community, which prevents women from protecting their interests. ${ }^{35}$ This societal construct has restricted women and indigenous women's (in particular) ability to inherit, own and control land, which is a vital resource for sustenance and sustainable development. Ndulo comments that traditionalists view customary law as an essential element to uphold traditional values and enhance human rights. ${ }^{36}$ Thus, customary law is described as a living set of rules upon which most indigenous societies base their practices and activities.

Indigenous communities everywhere view land as a collective resource, although various controversies have emerged regarding the claim to this right, especially claims related to ownership and control. ${ }^{37}$ By implication, no individual in the indigenous community could claim ownership of a piece of land, nor could the land be sold to non-indigenous people since the goal was to pass it on to posterity. ${ }^{38}$ The entire community had a collective right to these lands and the resources therein. ${ }^{39}$ Land and natural resources were considered ancestral gifts meant to be preserved and transmitted to the younger generations. ${ }^{40}$ In practice, traditional societies at that time were governed by customary rules, that is, a customary land tenure system which governed the relationship between humans, the land and its resources. ${ }^{41}$ Land was therefore held under a communal land tenure system. ${ }^{42}$ The local chief or family heads, usually the men, hold land in custody for the entire community/family, with the power to "lease" out the land to individuals according to their demands (farming, hunting or building). ${ }^{43}$ For instance, in Amodu Tijani $v$ The Secretary, Southern Province Nigeria ${ }^{44}$ the case

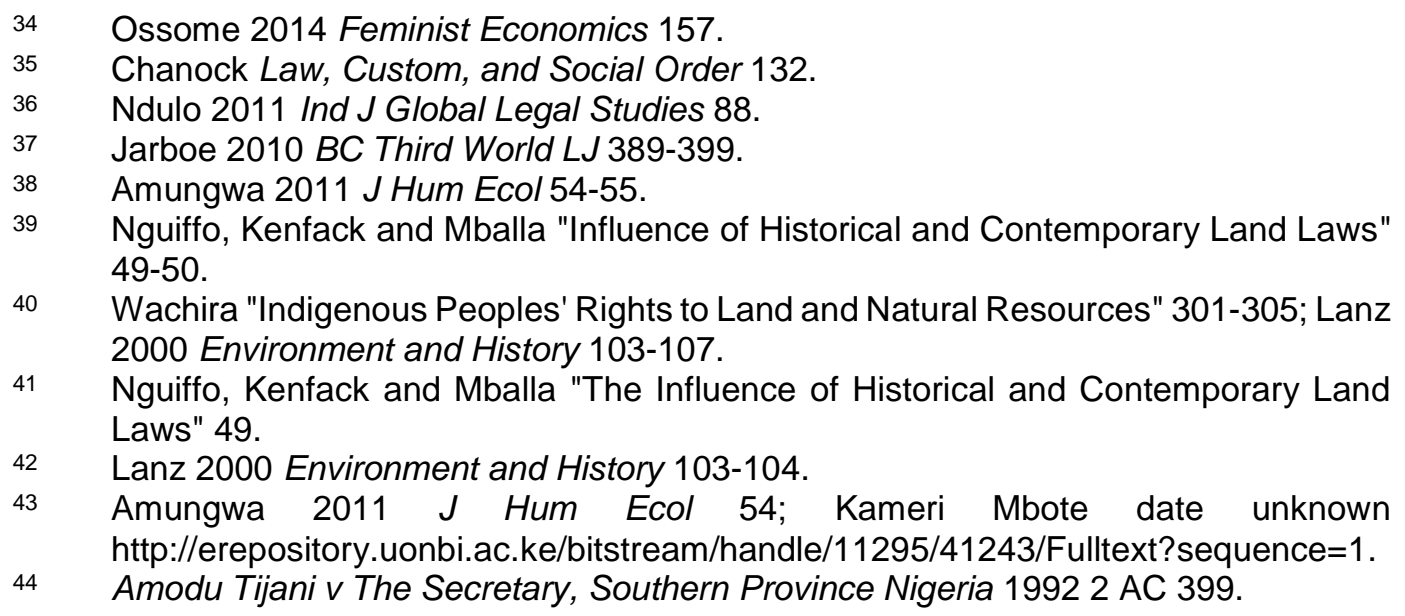

43 Amungwa $2011 \mathrm{~J}$ Hum Ecol 54; Kameri Mbote date unknown http://erepository.uonbi.ac.ke/bitstream/handle/11295/41243/Fulltext?sequence=1. Amodu Tijani v The Secretary, Southern Province Nigeria 19922 AC 399. 
concerned a dispute over compensation made in respect of land belonging to the Apapa community located in the then Colony of Nigeria. In accordance with the Public Lands Ordinance of 1903, the Governor had the right to possess for public purposes any land considered not in use, and to compensate the community through the Head Chief. The Head Chief held the land in trust for the community. In this case, the Head Chief challenged the compensation paid and demanded the full value of the land. The Supreme Court held that the appellant should be compensated in accordance with the Public Lands Ordinance 5 of 1903 on the grounds that he had provided full ownership and title to the land in question. The Court also held that the appellant should transfer the land to the Governor in full ownership, with the exception that the land was unoccupied, together with his title to collect rents or tribute, and that the compensation awarded be distributed amongst the community members in accordance with the Native Council District in agreement with the Governor.

Women generally do not experience challenges in accessing land for food production: the issue arises when it comes to complete control and ownership of land. ${ }^{45}$ Men dominate the decision-making process under customary law, especially as most of the land under the customary land tenure system is unregistered. ${ }^{46}$ As a result, they tend to make decisions regarding the security of tenure that discriminates against women. ${ }^{47}$ The responsibility for these discriminatory practices can be attributed to the functioning of the indigenous communities as patriarchies, which makes it difficult for women to be on a par with men, especially with regard to the control and ownership of land. ${ }^{48}$

Since land is a symbol of indigenous peoples' survival and culture, access to and control over land is crucial for their everyday existence..$^{49}$ Indigenous communities in Cameroon are governed by customary laws that are reluctant to incorporate land titling and ownership for women. The general perception is that women are weak and incompetent, and would be unable to manage and control lands even if they were granted ownership rights. ${ }^{50}$ Related studies reveal that women often change their status at marriage and can transfer the family's heritage to the man they love or marry. ${ }^{51}$ Thus

\footnotetext{
$45 \quad$ Sone $2012 \mathrm{~J}$ Soc Dev Afr 86.

46 Sone $2012 \mathrm{~J}$ Soc Dev Afr 86-87.

47 Sone 2012 J Soc Dev Afr 87-88.

48 World Rainforest Women 2016 http://wrm.org.uy/articles-from-the-wrmbulletin/section1/women-and-property-in-cameroon-laws-and-reality/.

$49 \quad$ Anaya 2005 Ariz J Int'l \& Comp L 7, 8.

50 Asiimwe and Crankshaw 2011 JLCR 8-9.

51 Sone 2012 J Soc Dev Afr 85.
} 
they do not deserve legal entitlement to land. ${ }^{52}$ To this effect, women can only have possession of land upon marriage or through what Sone and Fonjong, Sama-Lang and Fombe call matrikins and patrikins, which ultimately comes to an end when the marriage is terminated (usually upon divorce or the death of her husband). ${ }^{53}$ Even though the village representatives effectively manage this pattern of customary norms without conflicts, it subjects women to men's authority. ${ }^{54}$ In fact, customary law does not recognise women's right to land. Instead, traditional practices cause women to adopt an attitude of self-exclusion from tenure matters and to viewed land as a men's thing. ${ }^{55}$ This practice has greatly discouraged indigenous women in particular from investing in land, even though they are considered the major drivers in ensuring sustainable development, food security and poverty alleviation in their communities. ${ }^{56}$ It is against this backdrop that indigenous women are treated as mere peasants with no right to the ownership of land in their communities.

During the pre-colonial era indigenous women did not have rights to land, like their male counterparts. However, this generally did not have major implications for the women, as there was a vast amount of land that was communally owned. ${ }^{57}$ The situation was exacerbated by colonialism. At this point, it is significant to provide a brief historical background of the colonial period relating to access and the right to land for indigenous peoples and women in particular.

Cameroon has the dubious distinction of being the only African state that underwent the tutelage of three European powers at different times. ${ }^{58}$ It is beyond dispute that each European power, during its time in Cameroon shaped the political, legal and socio-economic development of the country to some extent, which negatively affected indigenous communities (in the areas under their administration). The German colonial rule lasted from 1884-1916. ${ }^{59}$ During the period of the German annexation, Kamerun (as the Germans commonly referred to it) became a German colony. ${ }^{60}$ Upon the

\footnotetext{
52 Sone 2012 J Soc Dev Afr 85.

53 Sone Concept of Equality and Access to Land in Cameroon 81; Fonjong, SamaLang and Fombe 2010 PGDT 157.

54 Sone 2012 J Soc Dev Afr 85-89.

55 World Rainforest Women 2016 http://wrm.org.uy/articles-from-the-wrmbulletin/section1/women-and-property-in-cameroon-laws-and-reality/.

$56 \quad$ Fonjong 2016 Africa Development 55.

$57 \quad$ Fonjong, Sama-Lang and Fombe 2010 PGDT 157.

$58 \quad$ Njoh 2013 IJURR 750.

59 Cameroon was later on placed under the mandate of the League of Nations and partitioned between France and Britain.

60 Lekane and Asuelime 2016 J Contemp Hist 135.
} 
discovery of some fertile areas for coffee production, the German colonial masters enacted the Crown Land Act of $1896 .{ }^{61}$ The aim was to deprive the local chiefs of their positions as custodians of traditional lands by imposing the doctrine of "alien rule". ${ }^{62}$ This permitted the German colonialist to own and control all unexploited land and transform the country into a German overseas territory. ${ }^{63}$ The "herron loss" land policy instituted by the Germans considered all unoccupied land as lands without owners and assumed these lands as theirs. ${ }^{64}$ This policy resulted in the gross disruption of indigenous communities. They were deprived of their ancestral lands, while indigenous administrations managed by local chiefs were destroyed. ${ }^{65}$ The outcome of this was that the Germans acquired huge tracts of land, which indigenous peoples had preserved for their traditional rites and burial sites, and the customary notion of land tenure was outlawed, aggravating the situation of indigenous women having no right to access, own and control of land. ${ }^{66}$

The issue of land ownership was not different under the British ${ }^{67}$ and French ${ }^{68}$ administration. After the defeat of the Germans, the country was partitioned into two areas. The English-speaking part (British Northern Cameroons and British Southern Cameroons) was placed under the colonial auspices of Britain. ${ }^{69}$ France assumed Trusteeship over the larger part of the territory as French Cameroun. The British administration adopted a system of indirect rule by importing the Land and Native Rights Ordinance of Northern Nigeria into Southern Cameroons in $1927 . .^{70}$ In addition, the major Land Tenure Law (Ordinance 1 of 1927) assigned control of all native land to the British Governor. To this end, all native lands with the exception of estates registered and recognised by the British Governor were native lands, of which he was the sole custodian. ${ }^{71}$ Thus, indigenous peoples were

61 Nguiffo, Kenfack and Mballa "Influence of Historical and Contemporary Land Laws" 3.

62 Geschiere 1993 Africa 151-152; Lang and Astadji 2018 GJAHSS 2.

63 Nguiffo, Kenfack and Mballa "Influence of Historical and Contemporary Land Laws" 3.

64 Sone 2012 J Soc Dev Afr 85-86.

$65 \quad$ Lekane and Asuelime $2016 \mathrm{~J}$ Contemp Hist 136.

66 Sone 2012 J Soc Dev Afr 85-86; Lekane and Asuelime 2016 J Contemp Hist 136.

67 The southern regions of Cameroon were administered by the British from 1914-1961 as an integral part of British Nigeria. The French, on the other hand, administered the French-speaking regions from 1916 to 1960 , when the country finally gained its independence.

$69 \quad$ Njoh et al 2017 Women's Stud Int Forum 2.

70 Nfah-Abbenyi 2016 Tydskrif vir Letterkunde 6-7.

71 Fonjong, Sama-Lang and Fon 2010 PDGT 159. 
not only stripped off their customary rights but also became mere occupiers of their land at the mercy of the Governor. ${ }^{72}$

The French administration in Cameroon was like the British. The urge to accumulate huge tracts of land was a priority for their administrators. The aim was to transfer what they referred to as uninhabited land - a legal fiction known as "terra nullius" or "terres vacantes et sans maittre" to the management and control of the French colonial authorities. ${ }^{73}$ Although this was met with some resistance, little success was recorded on the part of the local indigenes. Indigenous peoples were given usage rights only to cultivate food crops. In essence, the shadows of these practices still haunt the post-colonial indigenous women in today's Cameroon.

The word évolués was used to classify indigenous peoples who had accepted and adopted the European way of life. ${ }^{74}$ Using Fonjong, SamaLang and Fombe's words, "colonisation has tilted the gender balance in favour of the males", 75 most especially as the post-colonial government, inherited colonial policies and land grabbing has become the order of the day. This is why indigenous women are still grappling with the issue of the control and ownership of land. Customary practices have caused them to remain under the dependence of men. This practice incites petty conflicts in family circles.

\section{The legislative framework regulating land rights in Cameroon}

It may be observed that Cameroon's land tenure system is characterised by what scholars like Ossome term "good" modern law and "bad" tradition. ${ }^{76}$ This is a reference to the enactment of land reforms and the application of existing customary laws that regulate land issues in the country. In other words, the land ownership system is anchored in a purely patriarchal setting in Cameroon. The debate concerning women's land rights has for decades remained an unresolved and contentious issue in many academic debates, despite the country's commitment to guaranteeing property rights and ensuring gender equality for everyone, including indigenous women.

Section 2 of the Land and Native Rights Ordinance 1 of 1927.

Nguiffo, Kenfack and Mballa "Influence of Historical and Contemporary Land Laws" 3.

$74 \quad$ Lekane and Asuelime $2016 \mathrm{~J}$ Contemp Hist 140.

75 Fonjong, Sama-Lang and Fombe 2012 Ethics and Social Welfare 261.

76 Ossome 2014 Feminist Economics 155. 
The 1996 Constitution and the 1974 Land Ordinance in Cameroon are not gender-biased. Both laws enhance the right to property for citizens. For example, the Preamble to the 1996 Constitution stipulates that "the human person, without distinction as to race, religion, sex or belief, possesses inalienable and sacred rights." ${ }^{77}$ A simple and clear interpretation of this provision means that the Constitution prohibits any and every form of discrimination based on gender deterring people from enjoying their rights. As a matter of emphasis, the Constitution further provides that

[o]wnership shall mean the right guaranteed to every person by law to use, enjoy and dispose of property. No person shall be deprived thereof, save for public purposes and subject to the payment of compensation under conditions determined by law. ${ }^{78}$

A thorough reading of this provision implies that all people in the country (indigenous women inclusive) have exclusive rights not only to access and use but also to exercise absolute right of ownership over property, including land. Interestingly, the Constitution has expressly stated that "the State shall ensure the protection of minorities and shall preserve the rights of indigenous populations in accordance with the law."79 By implication, there is no legal justification as to why indigenous women should be denied the right to own and control land based on customary beliefs. ${ }^{80}$ Since land symbolises economic and political power, granting indigenous women the right of ownership would help empower and enable them be active drivers in all development processes and would encourage them to improve their productivity. ${ }^{81} \mathrm{~A}$ more effective measure will be allowing indigenous women to participate in government and be part of the decision-making process, especially on matters regarding land reform.

In addition, Cameroon has affirmed its attachment to ensuring equality in rights by invoking the fundamental principles enshrined in the Universal Declaration of Human Rights, ${ }^{82}$ the Charter of the United Nations and the African Charter on Human and Peoples' Rights, ${ }^{83}$ including all duly ratified

\footnotetext{
77 See para 4 of the Preamble to the Constitution of the Republic of Cameroon, 1996 to amend the Constitution of 2 June 1972 as amended in 2008.

78 See para 5(19) of the Preamble to the Constitution of the Republic of Cameroon, 1996 to amend the Constitution of 2 June 1972 as amended in 2008.

79 Para 5(2) of the Preamble to the Constitution of the Republic of Cameroon, 1996 to amend the Constitution of 2 June 1972 as amended in 2008.

80 Fonjong, Sama-Lang and Fombe 2012 Ethics and Social Welfare 263.

81 Fombe et al 2013 Ethics and Economics 76.

82 Universal Declaration on Human Rights (1948) (UDHR) 71.

83 African Charter on Human and Peoples' Rights (1981) (Banjul Charter).
} 
international conventions related to these instruments. ${ }^{84}$ In principle, international law is law and self-executing in Cameroon. For instance, Article 45 of the 1996 Constitution states that

... duly approved or ratified treaties and international agreements shall, following their publication, override national laws, provided the other party implements the said treaty or agreement. ${ }^{85}$

Based on the content of this constitutional provision, the application of any international instrument in Cameroon is automatic. ${ }^{86}$

Article 17 of the UDHR guarantees everyone's right to property and call on states to refrain from practices and policies that deprive anyone, indigenous peoples and women included, from enjoying this right. In a similar vein, Articles 18(3), 19 and 21 of the African Charter on Human and Peoples Rights emphasise the need to refrain from all forms of discrimination against anyone and the right to freely dispose of one's property. Articles $2(\mathrm{f})(\mathrm{g}), 5(\mathrm{a})$ and $16(\mathrm{~h})$ of the Convention for the Elimination of all Forms of Discrimination Against Women ${ }^{87}$ crowns it all by calling on states to eradicate customs and practices that violate women's rights. It also imposes an obligation on state parties to adopt effective and appropriate measures to ensure that all women exercise the right of ownership, acquisition, administration and disposition of property indiscriminately. Even though the above provisions do not specifically refer to indigenous women, the wording "everyone" or "all people" can be interpreted to include indigenous women. It has been argued that these provisions serve as a vital step towards securing the right to land of indigenous women. ${ }^{88}$ Related studies reveal that building on CEDAW, indigenous women anticipate finding a connection between international human rights instruments promoting their rights, and local values and practices that improve their rights, most especially their rights to land. ${ }^{89}$

Moreover, the rights of indigenous women to property are also echoed in the International Covenant on Civil and Political Rights; 90 the International

84 See para 5 of the Constitution of the Republic of Cameroon, 1996 to amend the Constitution of 2 June 1972 as amended in 2008. Article 45 of the Constitution of the Republic of Cameroon, 1996 to amend the Constitution of 2 June 1972 as amended in 2008. Njieassam Analysis of Legislative and Institutional Frameworks 106. Convention on the Elimination of all Forms of Discrimination against Women (1979) (CEDAW).

UN 2010 http://www.un.org/esa/socdev/unpfii/documents/BriefingNote6_GREY.pdf. UN 2010 http://www.un.org/esa/socdev/unpfii/documents/BriefingNote6_GREY.pdf. Articles 1, 2, 3, 26 and 27 of the International Covenant on Civil and Political Rights (1966) (ICCPR). 
Covenant on Economic, Social and Cultural Rights;91 and the UNDRIP. These international instruments specifically deal with the protection of the rights of indigenous peoples. ${ }^{92}$ All of the above international instruments have provisions that enhance indigenous women's property rights, bearing in mind gender issues and the principle of non-discrimination. Article 2 of the UNDRIP stipulates that:

[i]indigenous peoples and individuals are free and equal to other peoples and individuals and have the right to be free from any kind of discrimination, in the exercise of their rights, in particular that based on their indigenous origin and identity.

Although the UNDRIP has a non-binding status, all three international instruments impose an obligation on state parties to enact legislative and other measures that would help promote indigenous women's rights to land ownership and control.

Additionally, as mentioned earlier, the 1974 Land Ordinance is gender neutral. The laws encourage private property rights but recommend that these lands be titled and registered. ${ }^{93}$ The provision that insists on land registration as proof of land ownership poses significant challenges to indigenous peoples and women, who do not have any legal documentation to show proof of their entitlement to land. In essence, the customary practices in these settings are what Mafa et al call "gender blind", ${ }^{94}$ although Ndi and Batterbury argue that they are a trick to exert persistent male dominance over women. ${ }^{95}$ Allanana feels that they are a strategic way of exerting political and economic power over women to ensure that they remain subordinate in relation to property rights. ${ }^{96}$

From this analysis, it is clear that despite constitutional promises of equality in property rights, indigenous women's interests, in particular, are not considered, despite their significant contribution to the social well-being of their families and communities. It is acknowledged that indigenous women's rights to land ownership are violated and insecure under the overlapping provision of section 16 of the 1974 Land Ordinance and customary law. ${ }^{97}$ It is observed that existing land tenure systems, whether customary systems

91 Articles 1 and 5 of the International Covenant on Economic Social and Cultural Rights (1966) (ICESCR).

92 See Arts $1,2,17(3), 18,22$ and 25 of the UNDRIP.

93 Pemunta 2017 AJESD 70.

94 Mafa et al "Gender and Land Politics in Zimbabwe" 109-110.

$95 \quad$ Ndi and Batterbury 2017 Africa Spectrum 37.

$96 \quad$ Allanana 2013 ESJ 117.

97 Polavarapu 2013 Ga J Int'l \& Comp L 93-131. 
of regulation (in law or administration) or statutory formal systems, are rooted in unequal and discriminatory power structures and procedures. ${ }^{98}$ This pattern usually has great repercussions for local food security, given the high level of (indigenous women's) dependence on land for production in their communities. ${ }^{99}$ To indigenous women land is a symbol of spiritual, social and cultural identity, economic welfare, well-being and values. If their rights to land were given priority, this would guarantee their active role in government and in decision-making processes. ${ }^{100}$

\section{Gender inequality and its effects on indigenous women's right to land in Cameroon}

The question of gender inequality is of serious concern in most African societies, including Cameroon, especially as women's activities are severally narrowed in an informal and non-wage economy. ${ }^{101}$ Given that their activities are basically aimed at survival, the women involved in this domain do not have access to land. ${ }^{102}$ The basis for this argument is rooted in the way society has constructed different roles for women and girls, and men and boys. The inbuilt societal structures of domination seek to ensure that women remain permanently subordinated to men, as wives, daughters, sisters or widows. ${ }^{103}$ This renders women helpless, with little or no option to make decisions regarding their socio-economic development.

Social norms relating to gender represent society's most profound grasp of what it entails to be a "real" woman and a "real" man. ${ }^{104}$ The practices that arise from these assumptions are exacerbated in indigenous communities. The situation for indigenous women is particularly dire, as they experience especial discrimination due to their age-old history of marginalisation/suppression, including traditional discriminatory practices. ${ }^{105}$ Studies indicate that the triple discrimination faced by indigenous women stems from their ethnicity, gender and class. ${ }^{106}$ Building on the above, the principle of the indivisibility of rights negates their potential to fully exercise their human rights, especially those related to land

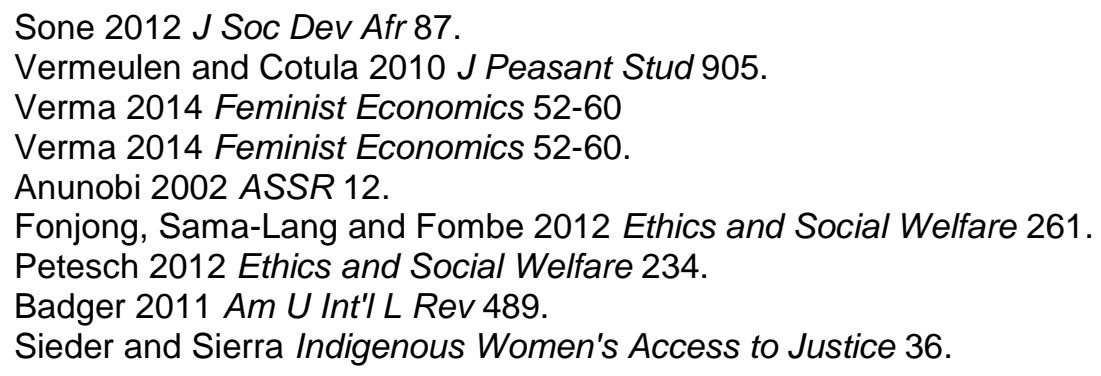


ownership, when the collective rights of their people are violated. ${ }^{107}$ In effect, indigenous women's ability to exercise their fundamental socioeconomic, cultural and political rights including their right to access and control land as articulated in international instruments is intricately linked to the right to self-determination in their territories. ${ }^{108}$ To this end, their inability to participate in public life and decision-making processes constrains them from accessing their land rights in Cameroon. This renders the possibility of achieving gender equality in Cameroon a pipedream.

The literature on women and land in sub-Saharan Africa dismisses prospects of women owning and controlling land through lineage or inheritance. ${ }^{109}$ It is estimated that over $90 \%$ of the population and particularly $80-85 \%$ of the women depend on land for their livelihood, as it is the only resource that provides direct benefits for peasants in urban and rural areas. ${ }^{110}$ Land is thus a vital asset in enhancing the country's gross domestic product and improving living conditions for local and indigenous communities. ${ }^{111}$ The significance of land to human existence implies that the refusal to grant indigenous women land rights undermines efforts to promote gender equality in a predominantly patriarchal society, as is Cameroon. This exclusion prevents them from enjoying their socioeconomic and political rights essential to attaining full membership of society and partaking in decisions regarding property rights as well as executing other duties in the community. ${ }^{112}$ It is submitted that the negation of indigenous women's right to land is an act of violence perpetrated against them, limits their ability to participate in the political sphere, and is an obstacle to making their voices heard at the domestic, local and national levels. Ndahinda expresses the opinion that the above practice impedes any progress towards the protection of indigenous peoples' rights in general. ${ }^{113}$

Foreign investors who acquire land for the extraction of natural resources, which the government terms economic development, exacerbate the situation regarding land rights in Cameroon. ${ }^{114}$ Moreda thinks that the

\footnotetext{
107 UN 2010 http://www.un.org/esa/socdev/unpfii/documents/BriefingNote6_GREY.pdf.

108 UN 2010 http://www.un.org/esa/socdev/unpfii/documents/BriefingNote6_GREY.pdf.

109 Fombe et al 2013 Ethics and Economics 75.

110 Fombe et al 2013 Ethics and Economics 74; Abbia et al 2016 IJRAFS 4-6.

111 Kameri-Mbote date unknown http://erepository.uonbi.ac.ke/bitstream/handle/11295/ 41243/Fulltext?sequence $=1$.

Kameri-Mbote date unknown http://erepository.uonbi.ac.ke/bitstream/handle/ $11295 /$

41243/Fulltext?sequence $=1$.

113 See generally Ndahinda Indigenousness in Africa.

114 Fombe et al 2013 Ethics and Economics 74-75.
} 
growing interest in land resources has instigated competition amongst different sectors over the same resource, depriving indigenous women of the abiity to access their traditional source of survival. ${ }^{115}$ Whitehead and Tsikata share the same view, stating that this has resulted in a historical shift from Cameroon's being a land of abundance to an acute scarcity of land, an alteration that has created stark gender inequality among the indigenous comunities in Cameroon. ${ }^{116}$ Thus, the creation in 2014 of the Ngoyla-Mintom nature reserve in a forest used by Baka women for food production resulted in their eviction and prevention from entering and accessing the area they used for food cultivation, ${ }^{117}$ this preventing them from continuing with their traditional and income-generating activities. This has contributed to food insecurity, further rural poverty, hunger and unemployment. Their inability to access the resource from which they would reap direct revenues to sustain their households has alienated them from their identity and society. According to Barume, failure by the post-colonial government to consider indigenous peoples' occupation of the land poses an obstacle for indigenous women's right to land in Cameroon. ${ }^{118}$

\section{The challenges to indigenous women's ability to own and control land}

Land is the basis of indigenous cultures, economies, spiritual practices and political systems, as well as a primary source of food production for indigenous women. It is also a traditional stronghold within which all family and developmental issues regarding the community originate. ${ }^{119}$ Therefore, land is a vital assert for indigenous women's cultural development and wellbeing. Unfortunately, there has been insecurity of land tenure for indigenous women in Cameroon, as access to, control over and ownership of this resource remain a male privilege. These embedded societal structures have negatively affected indigenous women's ability to contribute to the development of their community. The following section of this article examines the challenges encountered by indigenous women in accessing and controlling land.

\footnotetext{
115 Moreda 2017 Third World Q 698, 699.

116 Whitehead and Tsikata 2003 J Agrar Change 67, 68.

117 UN 2018 https://www.culturalsurvival.org/sites/default/files/UPR-report-Cameroon2017.pdf 5.

118 Barume Land Rights of Indigenous Peoples 38.

119 Ngwa "Introduction to Land and Rural Women in Cameroon" 3-8.
} 


\subsection{Lack of proper recognition}

The greatest challenge indigenous peoples' face worldwide is the lack of teir adequate recognition by national governments. This is compounded by the lack of a universally accepted definition and a refusal by African states to acknowledge the existence of this group of people on their continent. ${ }^{120}$ Most African governments maintain that the term is linked with a "premodern lifestyle". ${ }^{121}$ Based on this argument, it is obvious that the government of Cameroon has not taken a keen interest in providing constitutional recognition to its indigenous population, even though mention is made of it in the Preamble to the Constitution. Pelican argues that the absence of clarity as to the nature of the right and which group represents indigenous peoples in Cameroon is a major hindrance to granting them the special recognition and protection they deserve. ${ }^{122}$ No specific legislation in the country addresses indigenous peoples' issues. The lack of proper recognition has seriously limited indigenous women's ability to own and control land, even though their entire existence depends on it. Recent studies have identified two major challenges to indigenous peoples' constitutional recognition in their various states. Firstly, there is the fact that their societies have been completely "forgotten", and secondly is the fact that their core issues are kept in a "vacuum". ${ }^{123}$

It can be argued that involving indigenous women in politics would enable them to challenge decisions that are detrimental to their well-being, including their right to own and control land. Considering that land is a socioeconomic resource, granting indigenous women access to and control over land would empower them and enhance their level of economic productivity. As Rwegasira posits, land is a human right that encompasses all facets of life at all levels of human society. ${ }^{124}$ The significance of land to human survival and livelihoods is that those who own and control land indirectly control the lives of others. ${ }^{125}$ Indigenous women, in particular, are constantly in a state of dependence on men. It is essential that land reforms be redirected to address indigenous women's needs, such as to elevate their status, improve their skills and empower them to live independently. As Njoh

\footnotetext{
120 Pelican and Maruyama 2015 Afr Stud Monogr 49.

121 Viljoen "Reflections on the Legal Protection of Indigenous People's Rights in Africa" 75, 82.

122 Pelican 2013 Anthropol Today 13-14.

123 African Development Bank Group 2016 https://www.afdb.org/fileadmin/uploads/afdb/Documents/Publications/Development and_Indigenous_Peoples_in_Africa_En____v3_.pdf.

124 Rwegasira Land as a Human Right xviii.

125 Rwegasira Land as Human Right xviii.
} 
and Ananga have stated, enhancing women's economic proficiency might eliminate gender-based discrimination and improve their development outcomes. ${ }^{126}$ In effect, indigenous women would be actively represented in government and take part in decision-making processes, especially those that might have a negative impact on their livelihoods. Their inability to own land renders them under-developed and relegates them to a destitute position. As some scholars rightly suggest that women's access to and right to land will greatly improve their economic power, as they could use land as security to secure loans that would help them to improve their lifestyle, and develop them and their communities. ${ }^{127}$

\subsection{Poverty}

It is a shared premise that indigenous peoples globally suffer from pervasive forms of injustices and have remained the subjects of pervasive discrimination, inequality and genocide. ${ }^{128}$ Studies reveal that these discriminatory practices account for the fact that indigenous peoples live below the poverty line and are described as the poorest of the poor in the societies where they reside. ${ }^{129}$ In Cameroon, the Pygmies and Mbororo pastoralist communities are amongst the poorest of the poor, especially as their right to land and natural resources is often violated. ${ }^{130}$

If indigenous peoples in general are struggling to gain access to and control over traditionally owned lands, one can only imagine the situation of indigenous women. Graham and Wiessner see this as the reason why indigenous peoples and most especially women frequently experience a wide range of serious human rights violations such as inequality, political marginalisation, social exclusion and poverty. ${ }^{131}$ The unpalatable consequences of these practice is the impoverishment suffered by indigenous women, particularly with the existence of the double system of statutory law and indigenous customary law, which permits men to constantly manipulate the system to their advantage. ${ }^{132}$ The general presumption is that indigenous women lack the capacity to manage their

\footnotetext{
$126 \quad$ Njoh and Ananga 2016 Soc Indic Res 91.

127 Sone 2012 J Soc Dev Afr; Fonjong, Sama-Lang and Fombe 2012 Ethics and Social Welfare 261.

128 Money 2006/2007 Am Indian L Rev 553.

129 Swing, Davidov and Schwartz 2012 J Dev Soc 257.

130 UN Human Rights Council Report of the Independent Expert on minority issues, Addendum: Mission to Cameroon (2-11 September 2013) UN Doc A/HRC/25/56/Add.1 (2014).

131 Graham and Wiessner 2011 SAQ 403.

132 Kameri-Mbote "I Want It and I Want It Now" 5-6.
} 
own affairs even if they are granted access to and control over land. Their husbands, brothers or male family representatives will eventually manage the land. This perception has placed indigenous women in a peripheral position of acute poverty, as they have to depend solely on men for everything.

Additionally, the increasing need for resources to meet economic growth has increased the pressure on indigenous peoples' lands to the extent that indigenous women are running out of options for food security in the community. ${ }^{133}$ The persistent acquisition of vast amounts of land by foreign firms renders indigenous women helpless, causing a sharp decline in their living standards and trapping them in poverty with no access to the only means of their subsistence like food, fuel-wood and water. ${ }^{134}$ Ossome contends that a lack of critical information about their civic and political rights renders them even more vulnerable to manipulation and dispossession, especially as land deals are often justified on the basis of peoples' immediate needs. ${ }^{135}$ Land that is used for food production is usually viewed in the patriarchal Cameroonian society as not being properly developed. Thus, there is always a tendency to lose these lands to developmental projects initiated by government and other extractive companies. It is observed that the loss of ancestral lands is key to the systemic marginalisation and poor conditions indigenous women encounter every day. ${ }^{136}$

\subsection{Marginalisation}

Marginalisation is a common phrase used to describe the position of indigenous peoples. They are always victims of several human rights violations including social, economic, cultural and political marginalisation. Indigenous women in Cameroon who experience double discrimination in all spheres of life feel this marginalisation more. Their vulnerable status exposes them to gross human rights violations such as rape, prostitution, lack of inheritance rights, which is attributed to their high level of illiteracy, ignorance of their civic and political rights, and extreme poverty. This status, coupled with the way society perceives them, hinders them from owing and controlling land. For instance, Mbororo women are strictly viewed as objects, only good enough to be child bearers, housekeepers and providers of food for the family. They are not entitled to own land or to be consulted

\footnotetext{
133 Fonjong 2016 Africa Development 50-54.

134 Fonjong 2016 Africa Development 50.

135 Ossome 2014 Feminist Economics 164.

136 Wachira "Indigenous Peoples' Rights to Land and Natural Resources" 299.
} 
on issues relating to land. ${ }^{137}$ The society is strictly male-dominated in such a way that women do not have a say in any decisions concerning them and the family. Their defined gender roles, early and forced marriages and frequent childbirths, where boys are favoured over girls, result in their lower participation rates in school and higher drop-out rates than boys. ${ }^{138}$

\section{Conclusion}

In Cameroon indigenous women are often more marginalised than nonindigenous women. Although there are no reliable statistical data to back up this argument, it is observed that indigenous women record high incidences of rape, maternal and mortality rates, gender-based violence, preventable and communicable diseases, and illiteracy, and have limited rights to inheritance and property. ${ }^{139}$ Anunobi believes that despite women's significant role in development and food production, their status in most African societies does not reflect the sacrifices they make. ${ }^{140}$ For indigenous women, whose livelihoods and survival are tied to land, and who make invaluable contributions to their society in terms of food security and alleviating poverty, little effort has been made to address the situation. Customary norms perpetrating gender inequality have aggravated the situation of indigenous women in Cameroon. It is therefore essential for government policies to be responsive to the needs of indigenous women and to ensure their active engagement in decision-making processes, especially those relating to land rights. There is also a need to revisit land legislation in Cameroon to ensure that the provisions do not prevent women from accessing and controlling land. Most importantly, an inclusive system of government where indigenous women are active participants is highly recommended in Cameroon.

137 Unstructured interview with a few Mbororo students attending the University of Yaoundé II during a field trip on the 10 of February 2016 in Yaoundé, Cameroon.

138 See data collected in 2011 by the Cameroon Indigenous Women's Forum. The rate of illiteracy among Mbororo Fulani pastoralist women is around 98\%; Bouba 2012 http://www.ohchr.org/Documents/Issues/IPeoples/IFP/Aeisatu_Bouba_December_ 2012.pdf.

139 UN 2010 http://www.un.org/esa/socdev/unpfii/documents/BriefingNote6_GREY.pdf.

140 Anunobi 2002 ASSR 1. 


\section{Bibliography}

\section{Literature}

Abate and Kronk 2013 Tul Envtl LJ

Abate SR and Kronk EA "Commonality among Unique Indigenous Communities: An Introduction to Climate Change and its Impact on Indigenous Peoples" 2013 Tul Envtl LJ 179-195

Abbia et al 2016 IJRAFS

Abbia WA et al "Agriculture in Cameroon: Proposed Strategies to Sustain Productivity" 2016 IJRAFS 1-12

Allanana 2013 ESJ

Allanana MG "Patriarchy and Gender Inequality in Nigeria: The Way Forward" 2013 ESJ 115-144

Amungwa $2011 \mathrm{~J}$ Hum Ecol

Amungwa FA "The Evolution of Conflicts Related to Natural Resource Management in Cameroon" $2011 \mathrm{~J} \mathrm{Hum} \mathrm{Ecol} \mathrm{53-60}$

Anaya 2005 Ariz J Int'l \& Comp L

Anaya $\mathrm{J}$ "Indigenous Peoples' Participatory Rights in relation to Decisions about Natural Resources Extraction: The More Fundamental Issue of what Rights Indigenous Peoples have in Lands and Resources" 2005 Ariz J Int'I \& Comp L 7-17

Anunobi 2002 ASSR

Anunobi FO "Women and Development in Africa: From Marginalization to Gender Inequality" 2002 ASSR 1-24

Asiimwe and Crankshaw $2011 \mathrm{JLCR}$

Asiimwe FA and Crankshaw $O$ "The Impact of Customary Laws on Inheritance: A Case Study of Widows in Urban Uganda" 2011 JLCR 7-13

Badger 2011 Am U Int'I L Rev

Badger A "Collective v Individual Human Rights in Membership Governance for Indigenous Peoples" 2011 Am U Int'I L Rev 485-514

Bakang Mbock Speech

Bakang Mbock C Speech by the Ministry of Social Affairs at the Ceremony Marking the Celebration of the Second Edition of the International Day of 
Indigenous Peoples, Referred to in Cameroon as Marginal Populations (9 August 2009)

Barume Land Rights of Indigenous Peoples

Barume AK Land Rights of Indigenous Peoples in Africa: With Special Focus on Central, Eastern and Southern Africa $2^{\text {nd }}$ ed (Eks-Skolens Trykkeri Copenhagen 2014)

Chanock Law, Custom, and Social Order

Chanock M Law, Custom, and Social Order: The Colonial Experience in Malawi and Zambia (Heinemann Portsmouth 1998)

Coates Global History of Indigenous Peoples

Coates K A Global History of Indigenous Peoples: Struggle and Survival (MTM Johannesburg 2015)

Fombad 2014 JMAS

Fombad CM "Gender Equality in African Customary Law: Has the Male Ultimogeniture Rule any Future in Botswana?" 2014 JMAS 475-494

Fombe et al 2013 Ethics and Economics

Fombe LF et al "Securing Tenure for Sustainable Livelihoods: A Case of Women Land Ownership in Anglophone Cameroon" 2013 Ethics and Economics 73-86

Fonjong 2016 Africa Development

Fonjong L "Women's Land Rights and Working Conditions in Large-scale Plantations in Sub-Saharan Africa" 2016 Africa Development 49-69

Fonjong, Sama-Lang and Fombe 2010 PGDT

Fonjong F, Sama-Lang IF and Fombe LF "Assessment of the Evolution of Land Tenure System in Cameroon and Its Effects on Women's Land Rights and Food Security" 2010 PGDT 154-169

Fonjong, Sama-Lang and Fombe 2012 Ethics and Social Welfare Fonjong F, Sama-Lang IF and Fombe LF "Implications of Customary Practices on Gender Discrimination in Land Ownership in Cameroon" 2012 Ethics and Social Welfare 260-274

Fonjong, Fombe and Sama-Lang 2013 GeoJournal

Fonjong L, Fombe LF and Sama-Lang I "The Paradox of Gender Discrimination in Land Ownership and Women's Contribution to Poverty Reduction in Anglophone Cameroon" 2013 GeoJournal 575-589 
Geschiere 1993 Africa

Geschiere P "Chiefs and Colonial Rule in Cameroon: Inventing Chieftaincy, French and British Style" 1993 Africa: Journal of the International African Institute 151-175

Gilbert 2017 ICLQ

Gilbert J 'Litigating Indigenous Peoples' Rights in Africa: Potentials, Challenges and Limitations" 2017 ICLQ 657-686

Graham and Wiessner 2011 SAQ

Graham LM and Wiessner S "Indigenous Sovereignty, Culture, and International Human Rights Law" 2011 SAQ 403-427

Jarboe 2010 BC Third World LJ

Jarboe MR "Collective Rights to Indigenous Land in Carcieri v Salazar" 2010 BC Third World LJ 395-415

Kameri-Mbote "I Want It and I Want It Now"

Kameri-Mbote "I Want It and I Want It Now: Women and Land in Africa" in Heinrich Böll Stiftung Women and Land Rights: Questions of Access, Ownership and Control (Heinrich Böll Stiftung Cape Town 2013) 6-9

Lang and Astadji 2018 GJAHSS

Lang MK and Astadji M "Insights into Francophone Cameroonians' Experiences in Active Participation in Protestant Churches and Mission in Bamenda, Cameroon" 2018 GJAHSS 1-13

Lanz 2000 Environment and History

Lanz TJ "The Origins, Development and Legacy of Scientific Forestry in Cameroon" 2000 Environment and History 99-120

Lekane and Asuelime $2016 \mathrm{~J}$ Contemp Hist

Lekane GM and Asuelime L "One Country, Three Colonial Legacies: The Politics of Colonialism, Capitalism and Development in the Pre- and Postcolonial Cameroon" 2016 J Contemp Hist 134-153

Mafa et al "Gender and Land Politics in Zimbabwe"

Mafa $\mathrm{O}$ et al "Gender and Land Politics in Zimbabwe" in Mafa O et al (ed) Gender, Politics and Land Use in Zimbabwe 1980-2012 (Codesria Dakar 2015) 109-137 
Mawoung 2001 African Study Monographs

Mawoung GN "The Relationship between the Bakola and the Bantu Peoples of the Coastal Regions of Cameroon and their Perception of Commercial Forest Exploitation" 2001 African Study Monographs 209-235

Ministry of Justice Cameroon Report on Human Rights

Ministry of Justice Cameroon Report by the Ministry of Justice on Human Rights in Cameroon in 2009 (The Ministry Yaounde 2009)

Money 2006/2007 Am Indian L Rev

Money M "How the Organisation of American States Took the Lead: The Development of Indigenous Peoples' Rights in the Americas" 2006/2007 Am Indian L Rev 553-571

Moreda 2017 Third World Q

Moreda T "Large-scale Land Acquisitions, State Authority and Indigenous Local Communities: Insights from Ethiopia" 2017 Third World Q 698-716

Ndahinda Indigenousness in Africa

Ndahinda FM Indigenousness in Africa: A Contested Legal Framework for Empowerment of "Marginalized" Communities (Asser The Hague 2011)

Ndi and Batterbury 2017 Africa Spectrum

Ndi FA and Batterbury S "Land Grabbing and the Axis of Political Conflicts: Insights from Southwest Cameroon" 2017 Africa Spectrum 33-63

Ndulo 2011 Ind J Global Legal Studies

Ndulo M "African Customary Law, Customs, and Women's Rights" 2011 Ind J Global Legal Studies 87-120

Nfah-Abbenyi 2016 Tydskrif vir Letterkunde

Nfah-Abbenyi JM "Cameroon's National Literatures: An Introduction" 2016 Tydskrif vir Letterkunde 5-12

Nguh Implementing the Basic International Law Principles

Nguh A Implementing the Basic International Law Principles Relating to Indigenous Peoples' Rights: A Case Study of Cameroon (LLM-dissertation University of the Western Cape 2013)

Nguiffo, Kenfack and Mballa "Influence of Historical and Contemporary Land Laws"

Nguiffo S, Kenfack PE and Mballa N "The Influence of Historical and Contemporary Land Laws on Indigenous Peoples' Land Rights in 
Cameroon" in Couillard V (ed) Land Rights and the Forest Peoples of Africa: Historical, Legal and Anthropological Perspectives (Forest Peoples Programme Moreton-in-Marsh 2009) ch 2

Ngwa "Introduction to Land and Rural Women in Cameroon"

Ngwa NE "Introduction to Land and Rural Women in Cameroon" in Fonjong LN (ed) Issues on Women's Rights to Land in Cameroon (Langaa Research and Publishing Bamenda 2012) 1-18

Njieassam Analysis of Legislative and Institutional Frameworks

Njieassam EE An Analysis of Legislative and Institutional Frameworks Governing the Rights of Indigenous Peoples in Cameroon (PhD-thesis North-West University Mafikeng 2017)

Njoh 2013 IJURR

Njoh AJ "Equity, Fairness and Justice Implications of Land Tenure Formalization in Cameroon" 2013 IJURR 750-768

Njoh and Ananga 2016 Soc Indic Res

Njoh AJ and Ananga E "The Development Hypothesis of Women Empowerment in the Millennium Development Goals Tested in the Context Women's Access to Land in Africa" 2016 Soc Indic Res 91-104

Njoh et al 2017 Women's Stud Int Forum

Njoh AJ et al "Effects of Macro-economic Factors on Women's Formal Land Ownership Status in Cameroon" 2017 Women's Stud Int Forum 1-10

Ossome 2014 Feminist Economics

Ossome L "Can the Law Secure Women's Rights to Land in Africa? Revisiting Tensions between Culture and Land Commercialisation" 2014 Feminist Economics 155-177

Pelican 2009 American Ethnologist

Pelican M "Complexities of Indigeneity and Autochthony: An African Example" 2009 American Ethnologist 52-65

Pelican 2013 Anthropol Today

Pelican M "Insights from Cameroon: Five Years after the Declaration on the Rights of Indigenous Peoples" 2013 Anthropol Today 13-16

Pelican and Maruyama 2015 Afr Stud Monogr

Pelican $\mathrm{M}$ and Maruyama $\mathrm{J}$ "The Indigenous Rights Movement in Africa: Perspectives from Botswana and Cameroon" 2015 Afr Stud Monogr 49-74 
Pemunta 2017 AJESD

Pemunta NV "When 'Property Cannot Own Property': Women's Lack of Property Rights in Cameroon" 2017 AJESD 67-85

Petesch 2012 Ethics and Social Welfare

Petesch P "Unlocking Pathways to Women's Empowerment and Gender Equality: The Good, the Bad, and the Sticky" 2012 Ethics and Social Welfare 234-246

Polavarapu 2013 Ga J Int'l \& Comp L

Polavarapu A "Reconciling Indigenous and Women's Rights to Land in SubSaharan Africa" 2013 Ga J Int'l \& Comp L 93-131

Rwegasira Land as a Human Right

Rwegasira A Land as a Human Right: A History of Land Law and Practice in Tanzania (Mkuki na Nyota Dar es Salaam 2012)

Same and Greenen Discourses, Fragmentation and Coalitions

Same MT and Greenen S Discourses, Fragmentation and Coalitions: The Case of Herakles Farms' Large-Scale Land Deal in Cameroon (University of Antwerp Institute of Development Policy Antwerp 2015)

Sieder and Sierra Indigenous Women's Access to Justice Sieder R and Sierra MT Indigenous Women's Access to Justice in Latin America (Michelsen Institute Bergen 2010)

Sone Concept of Equality and Access to Land in Cameroon Sone PM The Concept of Equality and Access to Land in Cameroon: The Case of Anglophone Regions of Cameroon (PhD-thesis University of Buea 2011)

Sone 2012 J Soc Dev Afr

Sone PM "Access to Land in the Anglophone Regions of Cameroon: Challenges and Prospects" 2012 J Soc Dev Afr 85-112

Swing, Davidov and Schwartz 2012 J Dev Soc

Swing K, Davidov V and Schwartz B "Oil Development on Traditional Lands of Indigenous Peoples: Coinciding Perceptions on Two Continents" $2012 \mathrm{~J}$ Dev Soc 257-280

Verma 2014 Feminist Economics

Verma R "Land Grabs, Power, and Gender in East and Southern Africa: So, What's New?" 2014 Feminist Economics 52-75 
Vermeulen and Cotula $2010 \mathrm{~J}$ Peasant Stud

Vermeulen S and Cotula L "Over the Heads of Local People: Consultation, Consent and Recompense in Large-scale Land Deals for Biofuels Projects in Africa" $2010 \mathrm{~J}$ Peasant Stud 899-916

Viljoen "Reflections on the Legal Protection of Indigenous People"

Viljoen F "Reflections on the Legal Protection of Indigenous People's Rights in Africa" in Dersso S (ed) Perspectives on the Rights of Minorities and Indigenous Peoples in Africa (Pretoria University Law Press Pretoria 2010) 75-93

Wachira "Indigenous Peoples' Rights to Land and Natural Resources" Wachira GM "Indigenous Peoples' Rights to Land and Natural Resources" in Dersso S (ed) Perspectives on the Rights of Minorities and Indigenous Peoples in Africa (Pretoria University Law Press Pretoria 2010) 297-347

Whitehead and Tsikata $2003 \mathrm{~J}$ Agrar Change

Whitehead A and Tsikata D "Policy Discourse on Women's Land Rights in Sub-Sahara Africa: The Implications for the Re-turn to the Customary" 2003 J Agrar Change 67-112

\section{Case law}

Amodu Tijani v The Secretary, Southern Province Nigeria 19922 AC 399

\section{Legislation}

Constitution of the Republic of Cameroon, 1996 as amended

Crown Land Act, 1896

Land Law Ordinance No 74-1 of 6 July 1974

Land Tenure Law Ordinance 1 of 1927

Native Rights Ordinance 1 of 1916

Public Lands Ordinance 5 of 1903

International instruments

African Charter on Human and Peoples Rights (1981)

Charter of the United Nations (1945) 
Convention on the Elimination of all Forms of Discrimination against Women (1979)

ILO Indigenous and Tribal Peoples Convention No 169 (1989)

International Covenant on Civil and Political Rights (1966)

International Covenant on Economic Social and Cultural Rights (1966)

UN Human Rights Council Report of the Independent Expert on minority issues, Addendum: Mission to Cameroon (2-11 September 2013) UN Doc A/HRC/25/56/Add.1 (2014)

Universal Declaration on Human Rights (1948)

United Nations Declaration on the Rights of Indigenous Peoples (2007)

\section{Internet sources}

ACHPR 2010 http://www.achpr.org/states/cameroon/reports/2nd-20032005/

African Commission on Human and Peoples' Rights 2010 Cameroon: 2nd Periodic Report, 2003-2005 http://www.achpr.org/states/cameroon/reports/ 2nd-2003-2005/ accessed 21 February 2019

African Development Bank Group 2016 https://www.afdb.org/ fileadmin/uploads/afdb/Documents/Publications/Development_and_Indige nous_Peoples_in_Africa_En____v3_.pdf

African Development Bank Group 2016 Development and Indigenous Peoples in Africa https://www.afdb.org/fileadmin/uploads/afdb/ Documents/Publications/Development_and_Indigenous_Peoples_in_Afric a_En____v3_pdf accessed 27 February 2018

Anadolu Agency 2017 https://www.dailysabah.com/feature/2017/08/03/ inside-cameroons-pygmy-community-traditions-lifestyle-and-religion Anadolu Agency 2017 Inside Cameroon's Pygmy Community: Traditions, Lifestyle and Religion https://www.dailysabah.com/feature/2017/08/03/ inside-cameroons-pygmy-community-traditions-lifestyle-and-religion accessed 21 February 2019

Anon 2017 http://pubs.iied.org/pdfs/17448IIED.pdf Anon 2017 Indigenous Peoples' Land Rights in Cameroon: Progress till Date and Possible Futures http://pubs.iied.org/pdfs/17448IIED.pdf accessed 8 February 2018 
Anter 2011 https://www.modernghana.com/news/349849/1/who-are-thefulani-people-their-origins.html

Anter T 2011 Who are the Fulani People and their Origins? https://www.modernghana.com/news/349849/1/who-are-the-fulani-peopletheir-origins.html accessed 2 February 2019

Bouba $2012 \quad$ http://www.ohchr.org/Documents/lssues/IPeoples/IFP/ Aeisatu_Bouba_December_2012.pdf

Bouba A 2012 Mbororo Pastoralist, Cameroon http://www.ohchr.org/ Documents/Issues/IPeoples/IFP/Aeisatu_Bouba_December_2012.pdf accessed 9 April 2018

CEDD, RACOPY and FPP 2010 http://www.forestpeoples.org/ en/partners/ced/publication/2010/situation-indigenous-peoples-cameroonsupplementary-report-un-committe

CED, RACOPY and FPP 2010 The Situation of Indigenous Peoples in Cameroon: A Supplementary Report Submitted in Connection with Cameroon's 15th-19th Periodic Reports http://www.forestpeoples.org/ en/partners/ced/publication/2010/situation-indigenous-peoples-cameroonsupplementary-report-un-committe accessed 2 February 2019

Feiring 2013 http://www.landcoalition.org/sites/default/files/documents/ resources/InidgneousPeoplesRightsLandTerritoriesResources.pdf

Feiring B 2013 Indigenous Peoples' Rights to Lands, Territories, and Resources

http://www.landcoalition.org/sites/default/files/documents/resources/Inidgn eousPeoplesRightsLandTerritoriesResources.pdf accessed 30 March 2018

IFAD date unknown https://www.ifad.org/documents/10180/3629656a70f3-4c94-b58f-fd1e7ea2f4dc

IFAD date unknown Enhancing the Role of Indigenous Women in Sustainable Development: IFAD Experience with Indigenous in Latin America and Asia, Third Session of the Permanent Forum on Indigenous Issues https://www.ifad.org/documents/10180/3629656a-70f3-4c94-b58ffd1e7ea2f4dc accessed 30 March 2018

ILO 2015 https://www.ilo.org/gender/Informationresources/Publications/ WCMS_438854/lang--en/index.htm

ILO 2015 Indigenous Peoples in Cameroon: A Guide for Media Professionals

https://www.ilo.org/gender/Informationresources/Publications/WCMS_438 854/lang--en/index.htm accessed 10 February 2018 
Izsák 2012 https://www.right-docs.org/doc/a-hrc-19-56/

Izsák R 2012 Report of the Independent Expert on Minority Issues, Mission on Cameroon by UN Human Rights Council During the Twenty-fifth Session, Agenda Item 3, under the Topic the Promotion and Protection of all Human Rights, Civil, Political, Economic, Social and Cultural Rights, Including the Right to Development https://www.right-docs.org/doc/a-hrc19-56/ accessed 21 February 2019

Kameri-Mbote date unknown http://erepository.uonbi.ac.ke/bitstream/ handle/11295/41243/Fulltext?sequence $=1$

Kameri-Mbote $\mathrm{P}$ date unknown Gender Issues in Land Tenure under Customary Law http://erepository.uonbi.ac.ke/bitstream/handle/ 11295/41243/Fulltext?sequence=1 accessed 19 February 2018

Survival International date unknown http://wwwsurvivalinternationalorg/ tribes/pygmies

Survival International date unknown Tribes - Pygmies http://wwwsurvivalinternationalorg/tribes/pygmies accessed 2 February 2019

UN 2010 http://www.un.org/esa/socdev/unpfii/documents/Briefing Note6_GREY.pdf

UN Office of the Special Adviser on Gender Issues and Advancement of Women and the Secretariat of the United Nations Permanent Forum on Indigenous Issues 2010 Gender and Indigenous Peoples' Human Rights http://www.un.org/esa/socdev/unpfii/documents/BriefingNote6_GREY.pdf accessed 6 March 2018

UN 2018 https://www.culturalsurvival.org/sites/default/files/UPR-reportCameroon-2017.pdf

UN 2018 Observations on the State of Indigenous Human Rights in Cameroon Prepared for the 30th Session of the United Nations Human Rights Council - Universal Periodic Report https://www.culturalsurvival.org /sites/defaultffiles/UPR-report-Cameroon-2017.pdf accessed 22 February 2018

WIPO 2013 http://www.wipo.int/export/sites/www/tk/en/resources/pdf/ overview_customary_law.pdf

WIPO 2013 Customary Law, Traditional Knowledge and Intellectual Property: An Outline of the Issues http://www.wipo.int/export/sites/ www/tk/en/resources/pdf/overview_customary_law.pdf accessed 19 February 2018 
World Rainforest Women 2016 http://wrm.org.uy/articles-from-the-wrmbulletin/section1/women-and-property-in-cameroon-laws-and-reality/

World Rainforest Women 2016 Women and Property in Cameroon: Laws and Reality http://wrm.org.uy/articles-from-the-wrm-bulletin/section1/ women-and-property-in-cameroon-laws-and-reality/ accessed 19 February 2018

\section{List of Abbreviations}

ACHPR

Afr Stud Monogr

AJESD

Am Indian L Rev

Am U Int'I L Rev

Anthropol Today

Ariz J Int'I \& Comp L

ASSR

BC Third World LJ

CED

CEDAW

ESJ

FPP

Ga J Int'l \& Comp L

GJAHSS

ICCPR

ICESCR

ICLQ

IFAD
African Commission on Human and Peoples' Rights

African Study Monographs

African Journal Economic and Sustainable

Development

American Indian Law Review

American University International Law

Review

Anthropology Today

Arizona Journal of International and Comparative Law

African Social Science Review

Boston College Third World Law Journal

Centre pour l'Environnement et le Développement

Convention on the Elimination of all Forms of Discrimination against Women

European Scientific Journal

Forest Peoples Programme

Georgia Journal of International and Comparative Law

Global Journal of Arts, Humanities and Social Sciences

International Covenant on Civil and Political Rights

International Covenant on Economic, Social and Cultural Rights

International and Comparative Law

Quarterly

International Fund for Agricultural

Development 
IJRAFS

IJURR

ILO

Ind J Global Legal Studies

J Agrar Change

$\mathrm{J}$ Contemp Hist

J Dev Soc

J Hum Ecol

$J$ Peasant Stud

J Soc Dev Afr

JLCR

JMAS

PGDT

RACOPY

SAQ

Soc Indic Res

Third World Q

Tul Envtl LJ

UDHR

UN

UNDRIP

WIPO

Women's Stud Int Forum
International Journal of Research in Agriculture and Food Science International Journal of Urban and Regional Research

International Labour Organisation

Indiana Journal of Global Legal Studies

Journal of Agrarian Change

Journal of Contemporary History

Journal of Developing Societies

Journal of Human Ecology

Journal of Peasant Studies

Journal of Social Development in Africa

Journal of Law and Conflict Resolution

Journal of Modern African Studies

Perspectives on Global Development and Technology

Réseau Recherches Actions Concertées Pygmées

South Atlantic Quarterly

Social Indicators Research

Third World Quarterly

Tulane Environmental Law Journal

Universal Declaration on Human Rights

United Nations

United Nations Declaration on the Rights of Indigenous Peoples

World Intellectual Property Organisation

Women's Studies International Forum 